\title{
Natural Regeneration in Tropical Secondary Forest in Southern Amazonia, Brazil
}

\author{
Alexandre Ebert, Leandro Ribeiro Teixeira, Adriana Zanirato Contini da Silva, \\ Reginaldo Brito da Costa \\ Faculty of Forestry Engineering, Federal University of Mato Grosso, Cuiabá, Brazil \\ Email: ebertfloresta@yahoo.com.br
}

Received November $30^{\text {th }}$, 2013; revised January $3^{\text {rd }}$, 2014; accepted January $23^{\text {rd }}, 2014$

\begin{abstract}
Copyright (C 2014 Alexandre Ebert et al. This is an open access article distributed under the Creative Commons Attribution License, which permits unrestricted use, distribution, and reproduction in any medium, provided the original work is properly cited. In accordance of the Creative Commons Attribution License all Copyrights @ 2014 are reserved for SCIRP and the owner of the intellectual property Alexandre Ebert et al. All Copyright (C) 2014 are guarded by law and by SCIRP as a guardian.
\end{abstract}

\begin{abstract}
The study aimed to establish floral composition, diversity levels, category size, phytosociological structure, commercial use and ecological group of species present in the regeneration of open ombrophile forest in southern Amazon, Brazil. Data were collected at São Nicolau farm, in the municipality of Cotriguaçu, northwest of Mato Grosso state, coordinates $51^{\circ} 9^{\prime} 19.5^{\prime \prime S}$ and $58^{\circ} 14^{\prime} 53^{\prime \prime} \mathrm{W}$. One hundred plots of $10 \times 10$ m were allocated. All individuals between 29.9 and $59.9 \mathrm{~cm}$ had circumference at breast height (CAP) measure, with sub-plots of $5 \times 5 \mathrm{~m}$ which were measured in all subjects between 1:50 $\mathrm{m}$ in height $29.9 \mathrm{~cm}$ CAP and sub-plots of $2 \times 2 \mathrm{~m}$ for individuals between 0.30 to $1.5 \mathrm{~m}$ tall. The information obtained in the field were processed in excel spreadsheet. The results showed the occurrence of 610 individuals belonging to 82 species, 34 plant families, with a diversity index of Shannon \& Weaver's 2.77 . The index of value of importance showed species Protium robustum, Maquira calophilla and Inga fagifolium with greater ecological importance in fitocenose. The higher values for Natural Regeneration were the species Protium robustum, Maquira calophilla and Inga fagifolium with 16.42, 8.03 and 7.76 respectively.
\end{abstract}

Keywords: Vertical Structure; Ecological Analysis; Forest Management

\section{Introduction}

The fabulous Amazon's biodiversity has been the subject of numerous debates in different social spheres. With the increasing demand for forest resources and prospects of population growth, these demands are expected to increase, particularly for tropical timber. With this in mind society has been put on alert. What is the carrying capacity of natural environments to resist human interventions and conserve the ecological and genetic interrelationships among species? The answer to this question needs to meet the needs of the present without compromising the needs of future generations as it was referred by Burtland in the report (Our Common Future) in 1987.

Sustainable forest management aims at using forest resources while keeping forest biodiversity and resilience. Studies of forest and natural regeneration enable a better understanding of the effect of the extraction of wood in tropical forests (Park et al., 2005; Zimmerman \& Kormos, 2012), and as Araújo (2011) points out, it is important to know more about tree species behavior and natural regeneration to define the appropriate silvicultural management for forest species.

Forest management based on natural regeneration is accomplished by concentrating efforts on conserving biodiversity, therefore ensuring the vital functions of forests, as well as the continuity in the supply of various social and economic benefits (Nasi \& Frost, 2009). It is determined by studies and surveys which help activities, inventory planning and exploitation of timber.

Natural regeneration is the renewing of trees in a forest and provides natural replacement of individuals. It becomes essential to take this into account when exposing large areas of forest logging. Many forest species are endangered mainly as a result of pressure by the intensive exploitation due to their high economic value (Fontana et al., 2003; IBAMA, 2008; Hubel et al., 2008). Thus, it becomes necessary to carry out surveys and studies on specific ways to lead to replacement of forest stock, with the maintenance of the natural reproductive processes of regeneration.

Studies of aspects related directly or indirectly to natural regeneration include auto ecology, success stage and the effects of forest exploitation (Higushi et al., 1985). They are crucial when compared with studies conducted for mature individuals, or considered as inventory growth and future exploration, (Scolforo, 1998). The importance becomes more evident when one considers that the quantitative and qualitative characteristics of mature forest are intimately related to the dynamic processes of biotic and abiotic natural regeneration, which consequently will continue the maintenance of forest biodiversity.

Several factors can influence natural regeneration. Calegario (1998), for instance, suggests successional stages as determinant interacting climatic factors, as well as biotic, edaphic, physiographic and anthropogenic. 
In areas of the Amazon rainforest, the study of natural regeneration involves complex knowledge, due to the great diversity of species and functional processes related to ecological interactions, to microclimatic extracts provided by the forest and the diversity of geomorphologic environments. This study aimed to determine the floristic composition, diversity levels, size category, phytosociological, use group and the ecological group of species in the regeneration of rain forest the Southern Amazon, Brazil.

\section{Materials and Methods}

The study was conducted at São Nicolau farm, located in the municipality of Cotriguaçu, northwest of Mato Grosso state, Brazil (Figure 1). The farm belongs to the Brazilian branch of the Office National des Forêts (ONF Brazil), and has an area of $100,000 \mathrm{~km}^{2}$, of which $70,000 \mathrm{~km}^{2}$ are covered with secondary open rain forest, reforestation of $20,000 \mathrm{~km}^{2}$ with tree species intercropped with pasture and $10,000 \mathrm{~km}^{2}$ ha with riparian areas fragmented.

The farm lays in a region where weather prevails belonging to group A tropical rainy climate, (Brazil, 1982), with type climate "Am", common to the short period of drought and rainfall below $60 \mathrm{~mm}$ in the driest period year (June to September).

For data collection permanent plots were allocated by the method of sampling for fixed area plots distributed systematically in two stages (Pellico et al., 1997).

The original vegetation types of the study area comprises the typology Open Tropical Rain Forest (Brazil, 1982), submontane formation with palm trees. Its physiognomy shows large trees spaced grouped with palm trees presenting a number of features with large leaves and rough bark.

Altogether, there were 50 plots subdivided into two sub-plots totaling 100 sampling units measuring $100 \mathrm{~m}^{2}(10 \times 10 \mathrm{~m})$, in which were accounted all individuals measuring between 30 and $59 \mathrm{~cm}$ in circumference at breast height (HBC), 100 plots of $25 \mathrm{~m}^{2}(5 \times 5 \mathrm{~m})$, for all young individual trees, measuring between $1.5 \mathrm{~m}$ in height and $30 \mathrm{~cm}$ in circumference and subplots of $4 \mathrm{~m}^{2}(2 \times 2 \mathrm{~m})$ for regeneration of plants up to $1.5 \mathrm{~m}$ tall (Figure 2).

The identification and cataloging of species in the field were carried out by two practical identifiers and botanist Program Management of Tropical Forests PROMANEJO/FENF/UFMT. The identification and measurement of species, data were recorded on field sheets, containing botanical identification by common name, circumference at $1.3 \mathrm{~m}$ height above the ground, the circumference height and commercial height.

The data collected were processed in an MS-Excel ${ }^{\circledR}$ spreadsheet obtaining results through natural regeneration phytosociological structure parameters such as density, frequency and index of value of importance. To calculate the diversity of natural regeneration was used the diversity index of ShannonWeaver.

In size classification of natural regeneration, it was used the classification suggested by FAO (1971): Class CT1 or seedling: $0.3 \mathrm{~m}<\mathrm{h}<1.5 \mathrm{~m}$; seedlings or CT2: $1.5 \mathrm{~m}<\mathrm{h}<3.0 \mathrm{~m}$; CT3 or change established: $\mathrm{h}>3.0 \mathrm{~m} \mathrm{DBH}<5.0 \mathrm{~cm}$; CT4 or rod 1: 5.0 $\mathrm{cm}>\mathrm{DBH}<10 \mathrm{~cm}$; CT5 or dipstick 2: $10 \mathrm{~cm}<\mathrm{DBH}<20 \mathrm{~cm}$.

To determine the estimated natural regeneration it was used the methodology proposed by (Volpato, 1994), which uses the values of frequency and absolute abundance of each species in each size class.

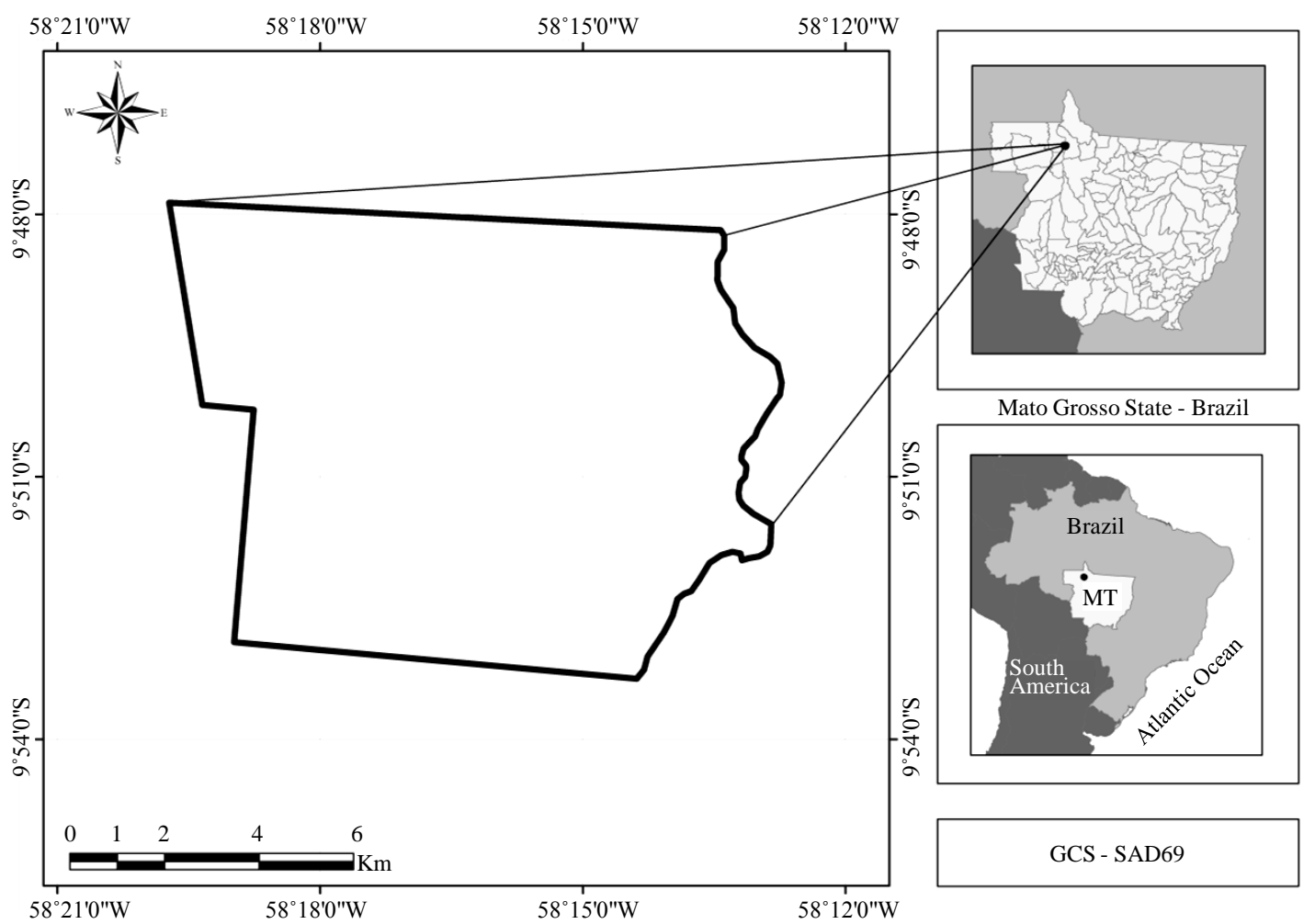

Figure 1.

Location map of the study area. 


\section{A. EBERT ET AL}

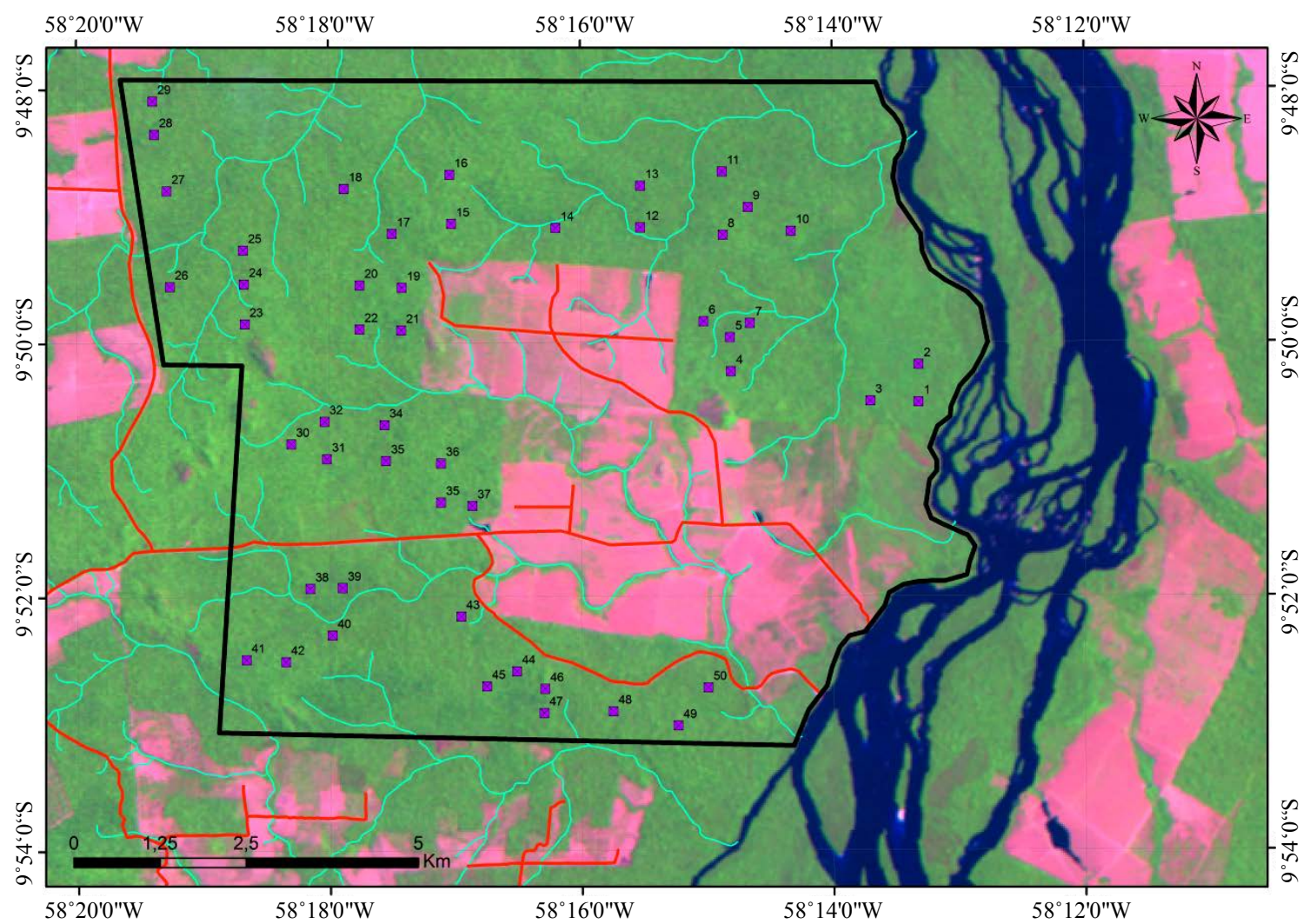

Figure 2.

Distribution of permanent plots, each was subdivided.

The abundance and relative frequency were calculated for each species in each class size, assuming that the denominator is constructed by summing the abundances and absolute frequencies of all species in all size classes. Further, it was estimated the natural regeneration by size class plant, adding partial values of relative frequency and relative abundance of natural regeneration by size class of plant studied, combining them into a unique expression as follows:

$$
\mathrm{RNC}_{\mathrm{ij}}=\left(\mathrm{Dr}_{\mathrm{ij}}+\mathrm{Fr}_{\mathrm{ij}}\right) / 2
$$

where $\mathrm{RNC}_{\mathrm{ij}}=$ estimate of the natural regeneration of the ith species in the jth class of plant size in percentage.

Determined an estimated total natural regeneration by species using the equation:

$$
\mathrm{RNT}_{\mathrm{i}}=\sum \mathrm{RNC}_{\mathrm{ij}}
$$

where $\mathrm{RNT}_{\mathrm{i}}=$ estimate of the Natural Regeneration total ith species.

The sum of the RNT of all species, as calculated above, equals 100 . Thus, each individual value, either by size class or kind, is being expressed in percentage.

\section{Results}

\section{Floristic Composition}

The survey for the inventory of natural regeneration of tree species identified a total of 610 individuals belonging to 82 species that are distributed in 34 botanical families. The families with the highest floristic diversity were: Fabaceae, with 17 genera and 18 species, Moraceae with 5 genera and 5 species, Melastomataceae with 3 genera and 4 species Burceraceae with 2 genera and 4 species, as shown in Table 1 .

For diversity analysis, by calculating the diversity index of Shannon \& Weaver $\left(\mathrm{H}^{\prime}\right)$ value obtained was $\mathrm{H}^{\prime}=2.77$.

\section{Analysis of the Distribution of Natural Regeneration in Succession Groups}

Categorization of natural regeneration of species between ecological groups grouped into size classes resulted in the data listed in Table 2.

It is observed in the prevalence pioneer species, totaling 271 individuals in 33 species, following the climax species with 204 individuals in 19 species and 132 individuals with secondary in 28 species (Figure 3).

These results suggest that the forest in study underwent recent exploratory interventions and based on resilience the same, succession processes is still being established, forming an initial structure of natural regeneration. This process is commonly viewed in areas that suffered extensive logging.

In group use of the species studied (Table 3 ) considered the supply and demand for timber products and non-timber species in the region, detecting a satisfactory number of commercial species, total: 38 species, 31 timber species 5 and the second food producing latex and oil. In the clustering of non-commercial trees were identified 44 species, of which at least 5 are used by local communities for the production of medicines, crafts and tool handles. It is noteworthy in this context, the species Siparuna guianensis Aublet used to relieve headaches, and Co- 
Table 1.

List of species raised in the study area, in alphabetical order by family, common and scientific name and its associated ecological group, and ecological group.

\begin{tabular}{|c|c|c|}
\hline Family & Specie & EG \\
\hline \multirow[t]{2}{*}{ Anacardiaceae } & Anacardium giganteum Hancock ex Engl. & CL \\
\hline & Astronium lecoitei Ducke & SE \\
\hline \multirow[t]{3}{*}{ Annonaceae } & Annona sp. & SE \\
\hline & Xylopia nitida Dunnal & PI \\
\hline & Xylopia frutensis Aubl. & PI \\
\hline \multirow[t]{3}{*}{ Apocinaceae } & Aspidosperma discolor A. DC. & SE \\
\hline & Aspidosperma sp. & SE \\
\hline & Aspidosperma desmanthum Mart. & SE \\
\hline \multirow[t]{4}{*}{ Arecaceae } & Orbignia speciosa Mart. & PA \\
\hline & Oenocarpus bataua Mart. & PA \\
\hline & Jacaranda copaia (Aubl.) D. Don. & PI \\
\hline & Tabebuia sp. & SE \\
\hline Bombacaceae & Ceiba pentandra (L.) Gaertn & PI \\
\hline \multirow[t]{4}{*}{ Burseraceae } & Trattinickia rhoifolia Willd. & CL \\
\hline & Protium robustum (Swart) D.M.Porter & CL \\
\hline & Trattinickia sp. & PI \\
\hline & Protium sp. & PI \\
\hline Cecropiaceae & Cecropia sp. & PI \\
\hline Celastraceae & Goupia glabra Aubl. & SE \\
\hline Elaeocarpaceae & Sloanea guianensis (Aubl.) ex Benth. & SE \\
\hline \multirow[t]{2}{*}{ Euphorbiaceae } & Sapium bogotense Huber. & SE \\
\hline & Sapium aureum H. Buek. & PI \\
\hline \multirow[t]{2}{*}{ Euphorbiaceae } & Mabea sp. & PI \\
\hline & $\begin{array}{l}\text { Hevea brasiliensis (Willd. Ex adr. de juss.) } \\
\text { Muell. Arg. }\end{array}$ & SE \\
\hline \multirow[t]{16}{*}{ Fabaceae } & Vatairea sericea Ducke & PI \\
\hline & Dinizia excelsa Ducke & PI \\
\hline & Myrocarpus sp. & PI \\
\hline & Sclerolobium paniculatum Vogel & CL \\
\hline & Torresea acreana Ducke. & SE \\
\hline & Dipterix odorata (Aubl.)Willd & SE \\
\hline & Copaífera sp. & CL \\
\hline & Lonchocarpus sericeus (Poir.) Kunth & PI \\
\hline & Albizia hasslerii (Chodat) Burr. & PI \\
\hline & Stryphnodendron guianensis (Aubl.) Benth & CL \\
\hline & Inga fagifolium Spruce ex Bth & PI \\
\hline & Inga dysantha Benth & PI \\
\hline & Hymenaea coubaril L. & SE \\
\hline & Dialium guianense (Aubl.) Sandwith & SE \\
\hline & Bauhinia macrostachya Wall. & PI \\
\hline & Enterolobium maximum Ducke & SE \\
\hline
\end{tabular}

\begin{tabular}{|c|c|c|}
\hline & $\begin{array}{l}\text { Myroxylon peruiferum L.f. } \\
\text { Abarema jupumba (Willd.) Britton \& Killip }\end{array}$ & $\begin{array}{l}\mathrm{CL} \\
\mathrm{SE}\end{array}$ \\
\hline Flacouticaceae & NI & PI \\
\hline Guttiferae & Moronobea pulchra Ducke & CL \\
\hline \multirow[t]{3}{*}{ Lauraceae } & Ocotea sp. & CL \\
\hline & Nectandra cuspidata Nees \& Mart & CL \\
\hline & Mezilaurus itauba (Meissn.) Taub. Ex Mez & SE \\
\hline \multirow[t]{2}{*}{ Lecythidaceae } & Eschweilera ovata (Cambess.) Miers & CL \\
\hline & Couratari guianensis Aulbl. & CL \\
\hline Loganiaceae & Antonia sp. & CL \\
\hline Malpighiaceae & Byrsonima densa (Poir.) & SE \\
\hline \multirow[t]{4}{*}{ Melastomataceae } & Mouriri sp. & PI \\
\hline & Bellucia grossularioides (L.) & SE \\
\hline & Miconia grandifolia Ule. & PI \\
\hline & Mouriri acutiflora Naudin. & PI \\
\hline \multirow[t]{2}{*}{ Meliaceae } & Cedrlela odorata L. & $\mathrm{SE}$ \\
\hline & Guarea silvatica DC. & $\mathrm{SE}$ \\
\hline Monimiaceae & Siparuna guianensis Aublet. & CL \\
\hline \multirow[t]{5}{*}{ Moraceae } & Maquira calophylla (Poeppig \& Endl.) Ducke & $\mathrm{SE}$ \\
\hline & Ficus gomelleira Kunth \& C.D. Bouché & CL \\
\hline & Clarisia racemosa Ruiz \& Pavón & PI \\
\hline & Helicostylis podogyne Ducke & CL \\
\hline & Brosimum galactodendron D. Don ex Sweet & PI \\
\hline Myristicaceae & Virola sp. & PI \\
\hline \multirow[t]{2}{*}{ Myrtaceae } & Eugenia bracteata (Willd.) Roxb ex DC. & SE \\
\hline & Eugenia melaccensis L. & SE \\
\hline \multirow[t]{2}{*}{ Polygonaceae } & Coccoloba sp. & PI \\
\hline & Triplaris surinamensis Cham. & PI \\
\hline Rubiaceae & Palicourea marcgravii St. Hill & SE \\
\hline Rutaceae & Zanthoxylum rhoifolium Lam. & PI \\
\hline Sapindaceae & Magonia sp. & PI \\
\hline \multirow[t]{2}{*}{ Sapotaceae } & Pouteria laurifólia (Gomes) Radlk. & SE \\
\hline & Sapindus cerasinus Benth. & PI \\
\hline \multirow[t]{2}{*}{ Simaroubaceae } & Simarouba amara Aubl. & PI \\
\hline & Simarouba sp. & PI \\
\hline \multirow[t]{2}{*}{ Sterculiaceae } & Theobroma subincamum Mart. & CL \\
\hline & $\begin{array}{c}\text { Theobroma grandiflorum (Willd. Ex. Spreng.) } \\
\text { Schum }\end{array}$ & CL \\
\hline \multirow[t]{2}{*}{ Tiliaceae } & Apeiba tibourbou Aubl. & PI \\
\hline & Apeiba albiflora Ducke & PI \\
\hline Verbenaceae & Vitex cymosa Bertero ex Spreng. & SE \\
\hline \multirow[t]{2}{*}{ Vochysiaceae } & Vochysia sp. & CL \\
\hline & Erisma uncinatuun Warm. & $\mathrm{SE}$ \\
\hline
\end{tabular}

Ecological grouping (EG) = PI, pioneer, SE, secondary, CL, climax, PA, Palmae. 
Table 2.

Relation between sizes classes of natural regeneration and their percenttages of individuals and number of species per stage successional.

\begin{tabular}{cccccc}
\hline \multirow{2}{*}{ Classe } & Size & $\mathbf{\%}$ & \multicolumn{3}{c}{ Species/Stage Sucessional } \\
\cline { 5 - 6 } & & & Pioneer & Secondary & Climax \\
\hline $\mathbf{1}$ & $1.5 \mathrm{~m}$ & $45 \%$ & 22 & 16 & 12 \\
$\mathbf{2}$ & $1.5<\mathrm{H}<3 \mathrm{~m}$ & $7 \%$ & 9 & 6 & 8 \\
\hline $\mathbf{3}$ & $\mathrm{H}>3$ e DAP $<5 \mathrm{~cm}$ & $0.8 \%$ & 3 & 1 & 0 \\
\hline $\mathbf{4}$ & $5 \mathrm{~cm}<\mathrm{DAP}<10 \mathrm{~cm}$ & $15 \%$ & 17 & 13 & 8 \\
\hline $\mathbf{5}$ & $10 \mathrm{~cm}<\mathrm{DAP}<20 \mathrm{~cm}$ & $30 \%$ & 25 & 13 & 11 \\
\hline
\end{tabular}

Table 3.

Number of species in natural regeneration by ecological group.

\begin{tabular}{ccccc}
\hline \multirow{2}{*}{ Classe } & \multicolumn{3}{c}{ Ecological group } & \multirow{2}{*}{ Total } \\
\cline { 2 - 4 } & Pioneer & Secondary & Climax & \\
\hline Comerciais & 15 & 17 & 32 & 62 \\
No Comerciais & 6 & 1 & 4 & 11 \\
Potenciais & 1 & 2 & 10 & 13 \\
Total & 22 & 20 & 50 & 86 \\
\hline
\end{tabular}

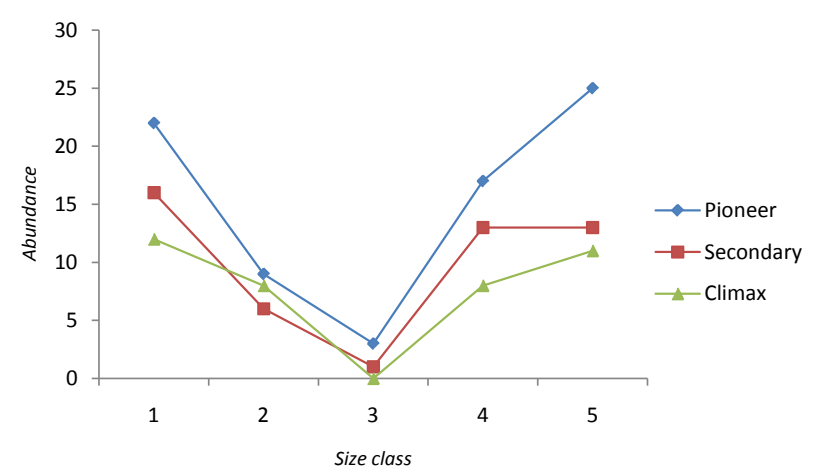

Figure 3.

Graphical representation of species by size class in succession stages.

paifera sp which is extracted oil much used in healing wounds and sore throats.

Values of Total Natural Regeneration of tree species with the highest importance, in descending order were; Protium robustum $16.42 \%$, Maquira callophylla to $8.03 \%$ and Inga fagifolium with $7.76 \%$, respectively (Table 4). Can observe the values of natural regeneration studied, with the respective values of absolute abundance by size class of the studied plants. These values allow us to analyze the regeneration by plant size.

\section{Phytosociological Parameters}

The total density of natural regeneration was 8.320 individuals/ha, and the individuals who had the highest values were: Protium robustum, Maquira callophylla, and Mouriri fagifolium and Inga sp respectively.

The amounts related to abundance, and absolute and relative frequency of each species Importance Value Index expanded, are shown in Table 5 . These values indicate the ecological importance of each species, i.e., its value in fitocenose studied.

The results related to the Amplified Importance Index Value which defines the ecological importance of the species within the community, allows making decisions about the management techniques based on guarantees replacement of existing individuals.

The species with the highest importance values obtained AIVI refer to tree and shrub species, highlighting the Protium robustum, a timber kind suffering strong pressure exploration in the Amazon region; however it is noted that the species responds positively to the processes natural regeneration. Figure 4 graphically illustrates the species that showed best AIVI.

\section{Discussion}

The current structure of the natural regeneration of the forest studied reflects intense logging in previous years, a fact that establishes succession stages presented. Despite not being able to establish the most intense period of exploration, it was noted that decades after logging still occur marked differences in the floristic composition and structure of ecological succession, especially in places where there were sharp impact on exploration, such as creating large clearings, stockyards and skid trails. The results obtained show that the structure of the forest is renewed by natural regeneration in face of disturbances caused by selective harvesting of timber. It's due probably by the high resilience of local environment.

The structure of natural regeneration in disturbed forests may suffer different arrangements according to the intensity. Hirai et al. (2012) and Garden et al. (2007) studying the effects of logging on natural regeneration in a forest, concluded that the floristic composition is modified in areas directly affected during exploitation, suffering changes along the years, occurring natural replacement of species serial stages. Species diversity was considered in a satisfactory level. Studies performed by Gamma et al. (2003), studying the natural regeneration in lowland forests in the Amazon estuary, they obtained similar results with $\mathrm{H}^{\prime}=3.05$, for comparison.

Almeida et al. (2012) evaluating phytosociology in managed forest in the municipality of Santarém, in Pará state, obtained $\mathrm{H}^{\prime}=4.39$. Probably, the differences found in the results obtained in studies of diversity refer to different vegetation types, and/or the intensity of explorations carried out in previous years.

The distribution of the number of plants, as expected, decreased with increasing class size, put in categories 2 and 3 (changes and changes made) there was considerable decrease of plants, which can be attributed to interspecific competition or related syndromes pollination and/or dispersing agents.

Results show high incidence of commercial species representing the natural regeneration of trees possibly exploited in previous years. Gomes et al. (2011) concluded in their studies conducted in managed rainforest in Bolivia that natural regeneration of tree species exploited continues after the intervention and does not compromise the structure of the natural regeneration of commercial species.

\section{Conclusion}

The results obtained in this study lead which species may fuel demand for raw material for timber and non-timber forest products, showing a useful strategy that allows the perpetuation of natural forests, supporting exploratory practices that consider ecological parameters maintenance of intra-and interspecific relationships. 
Table 4.

Relationship of the species with their respective values of absolute abundance by size classes (CT) values and estimated percentage of Natural Regeneration (NR).

\begin{tabular}{|c|c|c|c|c|c|c|c|c|}
\hline & Species & CT 1 & CT2 & CT3 & CT4 & CT5 & Total & NR \\
\hline 1 & Abarema jupumba (Willd.) Britton \& Killip & 0 & 0 & 0 & 0 & 1 & 1 & 0.19 \\
\hline 2 & Albizia hasslerii (Chodat) Burr. & 25 & 25 & 0 & 0 & 2 & 52 & 0.66 \\
\hline 3 & Anacardium giganteumHancock ex Engl. & 25 & 50 & 0 & 0 & 0 & 75 & 0.44 \\
\hline 4 & Annona sp. & 50 & 25 & 0 & 2 & 0 & 77 & 0.83 \\
\hline 5 & Antonia sp. & 350 & 50 & 0 & 1 & 0 & 401 & 3.24 \\
\hline 6 & Apeiba albiflora Ducke & 0 & 25 & 0 & 0 & 0 & 25 & 0.15 \\
\hline 7 & Apeiba tibourbou Aubl. & 50 & 0 & 0 & 0 & 1 & 51 & 0.54 \\
\hline 8 & Aspidosperma desmanthum Mart. & 0 & 0 & 0 & 1 & 0 & 1 & 0.17 \\
\hline 9 & Aspidosperma discolor A. DC. & 25 & 0 & 0 & 0 & 0 & 25 & 0.22 \\
\hline 10 & Aspidosperma sp. & 0 & 0 & 0 & 1 & 0 & 1 & 0.17 \\
\hline 11 & Astronium lecoitei Ducke & 150 & 0 & 0 & 0 & 1 & 151 & 1.40 \\
\hline 12 & Bauhinia macrostachya Wall. & 0 & 0 & 0 & 1 & 1 & 2 & 0.36 \\
\hline 13 & Bellucia grossularioides (L.) & 25 & 0 & 0 & 0 & 2 & 27 & 0.51 \\
\hline 14 & Brosimum galactodendron D. Don ex weet & 0 & 50 & 0 & 0 & 0 & 50 & 0.31 \\
\hline 15 & Byrsonima densa (Poir.) & 25 & 0 & 0 & 1 & 0 & 26 & 0.38 \\
\hline 16 & Cecropia sp. & 125 & 0 & 0 & 1 & 5 & 131 & 1.94 \\
\hline 17 & Cedrlela odorata $\mathrm{L}$. & 25 & 0 & 0 & 0 & 0 & 25 & 0.22 \\
\hline 18 & Ceiba pentandra (L.) Gaertn & 25 & 0 & 0 & 0 & 0 & 25 & 0.22 \\
\hline 19 & Clarisia racemosa Ruiz \& Pavón & 50 & 0 & 0 & 0 & 1 & 51 & 0.54 \\
\hline 20 & Coccoloba sp. & 50 & 0 & 0 & 2 & 0 & 52 & 0.68 \\
\hline 21 & Copaífera sp. & 0 & 0 & 0 & 0 & 1 & 1 & 0.19 \\
\hline 22 & Couratari guianensis Aulbl. & 0 & 0 & 0 & 0 & 1 & 1 & 0.19 \\
\hline 23 & Dialium guianense (Aubl.) Sandwith & 75 & 0 & 0 & 1 & 2 & 78 & 1.19 \\
\hline 24 & Dinizia excelsa Ducke & 25 & 0 & 0 & 0 & 0 & 25 & 0.22 \\
\hline 25 & Dipterix odorata(Aubl.)Willd & 25 & 0 & 0 & 0 & 0 & 25 & 0.22 \\
\hline 26 & Enterolobium maximum Ducke & 25 & 0 & 0 & 0 & 0 & 25 & 0.22 \\
\hline 27 & Erisma uncinatuun Warm. & 25 & 0 & 0 & 0 & 0 & 25 & 0.22 \\
\hline 28 & Eschweilera ovata (Cambess.) Miers & 50 & 50 & 0 & 4 & 4 & 108 & 1.82 \\
\hline 29 & Eugenia bracteata (Willd.) Roxb ex DC. & 175 & 50 & 0 & 7 & 7 & 239 & 3.37 \\
\hline 30 & Eugenia melaccensis L. & 25 & 0 & 0 & 0 & 0 & 25 & 0.22 \\
\hline 31 & Ficus gomelleira Kunth \& C.D. Bouché & 100 & 0 & 0 & 0 & 1 & 101 & 0.97 \\
\hline 32 & Goupia glabra Aubl. & 0 & 0 & 0 & 0 & 1 & 1 & 0.19 \\
\hline 33 & Guarea silvatica DC. & 0 & 0 & 0 & 2 & 7 & 9 & 1.41 \\
\hline 34 & Helicostylis podogyne Ducke & 0 & 0 & 0 & 0 & 4 & 4 & 0.59 \\
\hline 35 & Hevea brasiliensis (Willd.Ex adr.de juss.)Muell. Arg. & 25 & 50 & 0 & 0 & 0 & 75 & 0.52 \\
\hline 36 & Hymenaea coubaril L. & 0 & 25 & 0 & 0 & 0 & 25 & 0.15 \\
\hline 37 & Inga dysantha Benth & 25 & 0 & 0 & 0 & 0 & 25 & 0.22 \\
\hline 38 & Inga fagifolium Spruce ex Bth & 775 & 100 & 0 & 4 & 7 & 886 & 7.76 \\
\hline 39 & Jacaranda copaia (Aubl.) D. Don. & 0 & 0 & 0 & 0 & 3 & 3 & 0.49 \\
\hline 40 & Lonchocarpus sericeus (Poir.) Kunth & 25 & 0 & 0 & 1 & 0 & 26 & 0.38 \\
\hline 41 & Mabea sp. & 0 & 0 & 0 & 0 & 1 & 1 & 0.19 \\
\hline 42 & Magonia sp. & 0 & 0 & 0 & 0 & 1 & 1 & 0.19 \\
\hline 43 & Maquira calophylla (Poeppig \& Endl.)Ducke & 525 & 0 & 4 & 14 & 18 & 561 & 8.03 \\
\hline 44 & Mezilaurus itauba (Meissn.) Taub. Ex Mez & 0 & 50 & 0 & 0 & 2 & 52 & 0.69 \\
\hline 45 & Miconia grandifolia Ule. & 0 & 0 & 0 & 1 & 0 & 1 & 0.17 \\
\hline 46 & Moronobea pulchra Ducke & 0 & 0 & 0 & 1 & 0 & 1 & 0.17 \\
\hline 47 & Mouriri acutiflora Naudin. & 50 & 0 & 0 & 0 & 0 & 50 & 0.43 \\
\hline 48 & Mouriri sp. & 350 & 25 & 0 & 4 & 2 & 381 & 3.54 \\
\hline 49 & Myrocarpus sp. & 25 & 0 & 0 & 1 & 0 & 26 & 0.38 \\
\hline 50 & Myroxylon peruiferum L.f. & 0 & 0 & 0 & 0 & 1 & 1 & 0.19 \\
\hline 51 & Nectandra cuspidata Nees \& Mart & 125 & 50 & 0 & 1 & 5 & 181 & 2.42 \\
\hline 52 & $N I$ & 100 & 0 & 0 & 3 & 6 & 109 & 1.99 \\
\hline 53 & Ocotea sp. & 150 & 25 & 8 & 1 & 6 & 190 & 2.78 \\
\hline
\end{tabular}




\section{A. EBERT ET AL.}

Continued

\begin{tabular}{|c|c|c|c|c|c|c|c|c|}
\hline 54 & Oenocarpus bataua Mart. & 25 & 25 & 0 & 0 & 0 & 50 & 0.37 \\
\hline 55 & Orbignia speciosa Mart. & 25 & 0 & 0 & 0 & 0 & 25 & 0.22 \\
\hline 56 & Palicourea marcgravii St. Hill & 75 & 0 & 0 & 0 & 0 & 75 & 0.56 \\
\hline 57 & Pouteria laurifólia (Gomes) Radlk. & 20 & 0 & 0 & 0 & 10 & 30 & 2.38 \\
\hline 58 & Protium robustum (Swart) D.M.Porter & 1775 & 150 & 0 & 10 & 25 & 1960 & 16.42 \\
\hline 59 & Protium sp. & 50 & 0 & 0 & 0 & 2 & 52 & 0.64 \\
\hline 60 & Sapindus cerasinus Benth. & 0 & 0 & 0 & 2 & 0 & 2 & 0.33 \\
\hline 61 & Sapium aureum H. Buek. & 200 & 50 & 0 & 6 & 10 & 266 & 3.91 \\
\hline 62 & Sapium bogotense Huber. & 0 & 0 & 0 & 0 & 1 & 1 & 0.19 \\
\hline 63 & Sclerolobium paniculatum Vogel & 0 & 25 & 0 & 1 & 1 & 27 & 0.42 \\
\hline 64 & Simarouba amara Aubl. & 25 & 0 & 0 & 0 & 2 & 27 & 0.60 \\
\hline 65 & Simarouba sp. & 0 & 0 & 0 & 1 & 1 & 2 & 0.36 \\
\hline 66 & Siparuna guianensis Aublet. & 25 & 50 & 0 & 0 & 0 & 75 & 0.52 \\
\hline 67 & Sloanea guianensis (Aubl.) ex Benth. & 0 & 0 & 0 & 1 & 0 & 1 & 0.17 \\
\hline 68 & Stryphnodendron guianensis(Aubl.) Benth & 0 & 0 & 0 & 0 & 1 & 1 & 0.19 \\
\hline 69 & Tabebuia sp. & 25 & 0 & 0 & 0 & 0 & 25 & 0.22 \\
\hline 70 & Theobroma grandiflorum (Willd. Ex. Spreng.) Schum & 125 & 0 & 0 & 4 & 2 & 131 & 1.87 \\
\hline 71 & Theobroma subincamum Mart. & 50 & 0 & 0 & 2 & 7 & 59 & 1.93 \\
\hline 72 & Torresea acreana Ducke. & 0 & 0 & 0 & 1 & 0 & 1 & 0.17 \\
\hline 73 & Trattinickia rhoifolia Willd. & 200 & 25 & 0 & 3 & 5 & 233 & 2.99 \\
\hline 74 & Trattinickia sp. & 50 & 0 & 0 & 0 & 2 & 52 & 0.73 \\
\hline 75 & Triplaris surinamensis Cham. & 25 & 0 & 4 & 1 & 5 & 35 & 1.39 \\
\hline 76 & Vatairea sericea Ducke & 0 & 0 & 0 & 1 & 3 & 4 & 0.74 \\
\hline 77 & Virola sp. & 225 & 25 & 4 & 2 & 3 & 259 & 2.88 \\
\hline 78 & Vitex cymosa Bertero ex Spreng. & 125 & 175 & 0 & 4 & 5 & 309 & 3.08 \\
\hline 79 & Vochysia sp. & 0 & 0 & 0 & 0 & 1 & 1 & 0.19 \\
\hline 80 & Xylopia frutensis Aubl. & 75 & 0 & 0 & 1 & 1 & 77 & 0.92 \\
\hline 81 & Xylopia nitida Dunnal & 0 & 25 & 0 & 1 & 2 & 28 & 0.61 \\
\hline \multirow[t]{2}{*}{82} & Zanthoxylum rhoifolium Lam. & 0 & 0 & 0 & 0 & 1 & 1 & 0.19 \\
\hline & Totais & 6820 & 1200 & 20 & 96 & 184 & 8320 & 100 \\
\hline
\end{tabular}

Table 5.

List of species and their phytosociological parameters.

\begin{tabular}{lcccccc}
\hline & Nome cientifico & AARN & ARRN & FARN & FRRN & IVIA \\
\hline 1 & Abarema jupumba (Willd.) Britton \& Killip & 1 & 0.16 & 1 & 0.26 & 0.62 \\
2 & Albizia hasslerii (Chodat) Burr. & 4 & 0.66 & 3 & 0.77 & 2.15 \\
3 & Anacardium giganteumHancock ex Engl. & 3 & 0.49 & 2 & 0.51 & 1.49 \\
4 & Annona sp. & 5 & 0.82 & 4 & 1.03 & 2.77 \\
5 & Antonia sp. & 17 & 2.79 & 14 & 3.59 & 11.67 \\
6 & Apeiba albiflora Ducke & 1 & 0.16 & 1 & 0.26 & 0.58 \\
7 & Apeiba tibourbou Aubl. & 3 & 0.49 & 2 & 0.51 & 1.59 \\
8 & Aspidosperma desmanthum Mart. & 1 & 0.16 & 1 & 0.26 & 0.60 \\
9 & Aspidosperma discolor A. DC. & 1 & 0.16 & 1 & 0.26 & 0.65 \\
10 & Aspidosperma sp. & 1 & 0.16 & 1 & 0.26 & 0.60 \\
11 & Astronium lecoitei Ducke & 7 & 1.15 & 6 & 1.54 & 4.46 \\
12 & Bauhinia macrostachya Wall. & 2 & 0.33 & 2 & 0.51 & 1.22 \\
13 & Bellucia grossularioides (L.) & 3 & 0.49 & 2 & 0.51 & 1.57 \\
15 & Brosimum galactodendron D. Don ex weet & 2 & 0.33 & 2 & 0.51 & 1.19 \\
16 & Byrsonima densa (Poir.) & 2 & 0.33 & 2 & 0.51 & 1.24 \\
\hline
\end{tabular}


Continued

\begin{tabular}{|c|c|c|c|c|c|c|}
\hline 17 & Cedrlela odorata L. & 1 & 0.16 & 1 & 0.26 & 0.65 \\
\hline 18 & Ceiba pentandra (L.) Gaertn & 1 & 0.16 & 1 & 0.26 & 0.65 \\
\hline 19 & Clarisia racemosa Ruiz \& Pavón & 3 & 0.49 & 2 & 0.51 & 1.59 \\
\hline 20 & Coccoloba sp. & 4 & 0.66 & 3 & 0.77 & 2.19 \\
\hline 21 & Copaífera sp. & 1 & 0.16 & 1 & 0.26 & 0.62 \\
\hline 22 & Couratari guianensis Aulbl. & 1 & 0.16 & 1 & 0.26 & 0.62 \\
\hline 23 & Dialium guianense (Aubl.) Sandwith & 6 & 0.98 & 6 & 1.54 & 3.86 \\
\hline 24 & Dinizia excelsa Ducke & 1 & 0.16 & 1 & 0.26 & 0.65 \\
\hline 25 & Dipterix odorata(Aubl.)Willd & 1 & 0.16 & 1 & 0.26 & 0.65 \\
\hline 26 & Enterolobium maximum Ducke & 1 & 0.16 & 1 & 0.26 & 0.65 \\
\hline 27 & Erisma uncinatuun Warm. & 1 & 0.16 & 1 & 0.26 & 0.65 \\
\hline 28 & Eschweilera ovata (Cambess.) Miers & 12 & 1.97 & 8 & 2.05 & 6.25 \\
\hline 29 & Eugenia bracteata (Willd.) Roxb ex DC. & 23 & 3.77 & 12 & 3.08 & 11.77 \\
\hline 30 & Eugenia melaccensis L. & 1 & 0.16 & 1 & 0.26 & 0.65 \\
\hline 31 & Ficus gomelleira Kunth \& C.D. Bouché & 5 & 0.82 & 4 & 1.03 & 2.99 \\
\hline 32 & Goupia glabra Aubl. & 1 & 0.16 & 1 & 0.26 & 0.62 \\
\hline 33 & Guarea silvatica DC. & 9 & 1.48 & 6 & 1.54 & 4.97 \\
\hline 34 & Helicostylis podogyne Ducke & 4 & 0.66 & 2 & 0.51 & 1.92 \\
\hline 35 & Hevea brasiliensis (Willd.Ex adr.de juss.) Muell. Arg. & 3 & 0.49 & 3 & 0.77 & 1.83 \\
\hline 36 & Hymenaea coubaril L. & 1 & 0.16 & 1 & 0.26 & 0.58 \\
\hline 37 & Inga dysantha Benth & 1 & 0.16 & 1 & 0.26 & 0.65 \\
\hline 38 & Inga fagifolium Spruce ex Bth & 46 & 7.54 & 28 & 7.18 & 33.17 \\
\hline 39 & Jacaranda copaia (Aubl.) D. Don. & 3 & 0.49 & 2 & 0.51 & 1.58 \\
\hline 40 & Lonchocarpus sericeus (Poir.) Kunth & 2 & 0.33 & 2 & 0.51 & 1.24 \\
\hline 41 & Mabea sp. & 1 & 0.16 & 1 & 0.26 & 0.62 \\
\hline 42 & Magonia sp. & 1 & 0.16 & 1 & 0.26 & 0.62 \\
\hline 43 & Maquira calophylla (Poeppig \& Endl.)Ducke & 54 & 8.85 & 26 & 6.67 & 33.42 \\
\hline 44 & Mezilaurus itauba (Meissn.) Taub. Ex Mez & 4 & 0.66 & 4 & 1.03 & 2.45 \\
\hline 45 & Miconia grandifolia Ule. & 1 & 0.16 & 1 & 0.26 & 0.60 \\
\hline 46 & Moronobea pulchra Ducke & 1 & 0.16 & 1 & 0.26 & 0.60 \\
\hline 47 & Mouriri acutiflora Naudin. & 2 & 0.33 & 2 & 0.51 & 1.31 \\
\hline 48 & Mouriri sp. & 21 & 3.44 & 13 & 3.33 & 12.54 \\
\hline 49 & Myrocarpus sp. & 2 & 0.33 & 2 & 0.51 & 1.24 \\
\hline 50 & Myroxylon peruiferum L.f. & 1 & 0.16 & 1 & 0.26 & 0.62 \\
\hline 51 & Nectandra cuspidata Nees \& Mart & 13 & 2.13 & 12 & 3.08 & 8.19 \\
\hline 52 & $N I$ & 13 & 2.13 & 7 & 1.79 & 6.54 \\
\hline 53 & Ocotea sp. & 16 & 2.62 & 13 & 3.33 & 9.54 \\
\hline 54 & Oenocarpus bataua Mart. & 2 & 0.33 & 2 & 0.51 & 1.23 \\
\hline 55 & Orbignia speciosa Mart. & 1 & 0.16 & 1 & 0.26 & 0.65 \\
\hline 56 & Palicourea marcgravii St. Hill & 3 & 0.49 & 2 & 0.51 & 1.66 \\
\hline 57 & Pouteria laurifólia (Gomes) Radlk. & 15 & 2.46 & 8 & 2.05 & 8.18 \\
\hline 58 & Protium robustum (Swart) D.M.Porter & 112 & 18.36 & 39 & 10.00 & 104.29 \\
\hline 59 & Protium sp. & 4 & 0.66 & 2 & 0.51 & 1.89 \\
\hline 60 & Sapindus cerasinus Benth. & 2 & 0.33 & 2 & 0.51 & 1.21 \\
\hline 61 & Sapium aureum H. Buek. & 26 & 4.26 & 14 & 3.59 & 13.85 \\
\hline 62 & Sapium bogotense Huber. & 1 & 0.16 & 1 & 0.26 & 0.62 \\
\hline 63 & Sclerolobium paniculatum Vogel & 3 & 0.49 & 2 & 0.51 & 1.46 \\
\hline 64 & Simarouba amara Aubl. & 3 & 0.49 & 3 & 0.77 & 1.91 \\
\hline 65 & Simarouba sp. & 2 & 0.33 & 2 & 0.51 & 1.22 \\
\hline 66 & Siparuna guianensis Aublet. & 3 & 0.49 & 3 & 0.77 & 1.83 \\
\hline
\end{tabular}


Continued

\begin{tabular}{lcccccc}
\hline 67 & Sloanea guianensis (Aubl.) ex Benth. & 1 & 0.16 & 1 & 0.26 & 0.60 \\
68 & Stryphnodendron guianensis (Aubl.) Benth & 1 & 0.16 & 1 & 0.26 & 0.62 \\
69 & Tabebuia sp. & 1 & 0.16 & 1 & 0.26 & 0.65 \\
70 & Theobroma grandiflorum (Willd. Ex. Spreng.) Schum & 11 & 1.80 & 8 & 2.05 & 6.18 \\
71 & Theobroma subincamum Mart. & 11 & 1.80 & 9 & 2.31 & 6.62 \\
72 & Torresea acreana Ducke. & 1 & 0.16 & 1 & 0.26 & 0.60 \\
73 & Trattinickia rhoifolia Willd. & 17 & 2.79 & 13 & 3.33 & 10.12 \\
74 & Trattinickia sp. & 4 & 0.66 & 3 & 0.77 & 2.23 \\
75 & Triplaris surinamensis Cham. & 8 & 1.31 & 7 & 1.79 & 4.78 \\
76 & Vatairea sericea Ducke & 4 & 0.66 & 4 & 1.03 & 2.52 \\
77 & Virola sp. & 16 & 2.62 & 13 & 3.33 & 9.82 \\
78 & Vitex cymosa Bertero ex Spreng. & 21 & 3.44 & 13 & 3.33 & 11.04 \\
79 & Vochysia sp. & 1 & 0.16 & 1 & 0.26 & 0.62 \\
80 & Xylopia frutensis Aubl. & 5 & 0.82 & 4 & 1.03 & 2.88 \\
81 & Xylopia nitida Dunnal & 4 & 0.66 & 3 & 0.77 & 2.10 \\
& Zanthoxylum rhoifolium Lam. & 1 & 0.16 & 1 & 0.26 & 0.62 \\
\hline
\end{tabular}

AANR: Absolute Abundance of natural regeneration; ARNR: Abundance concerning natural regeneration; AFNR: Absolute frequency of natural regeneration; RFNR: Relative frequency of natural regeneration; AIVI: Index magnified importance.

AIVI

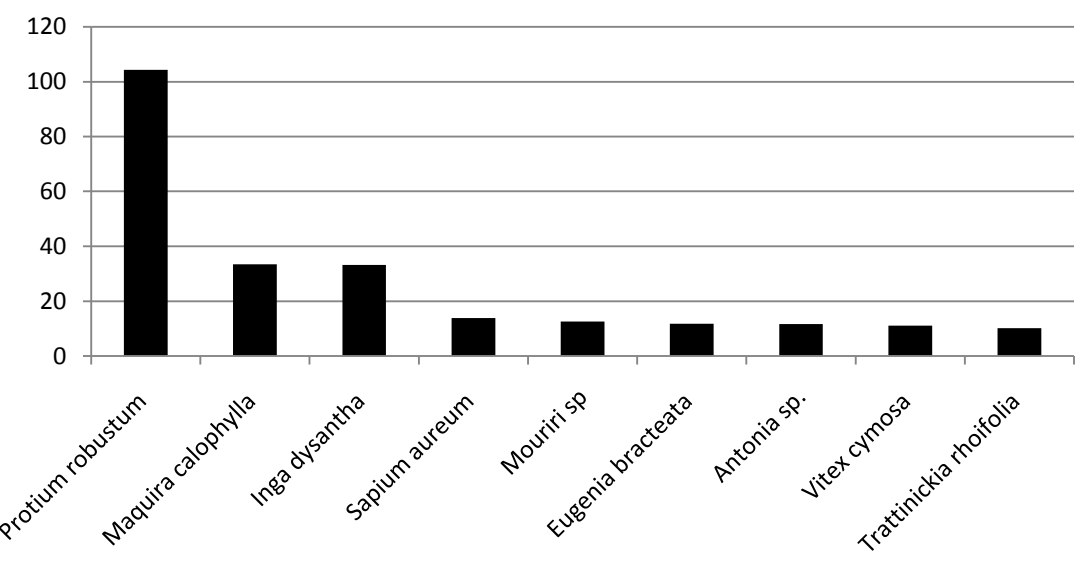

Figure 4.

Graphic illustration of the species with the highest Amplified Importance Index Value.

\section{Acknowledgements}

ONF Brazil for all the logistical support for the work done in the field, and the Coordination of Improvement of Higher Level Personnel—CAPES for the scholarship granted.

\section{REFERENCES}

Almeida, L. S., Gama, J. R. V., Oliveira, F. A., Carvalho, O. P., Gonçalves, D. C. M., \& Araújo, G. C. (2012). Fitossociologia e uso múltiplo de espécies arbóreas em floresta manejada, Comunidade Santo Antonio, município de Santarém, Estado do Pará. Acta Amazônica, 42, 185-194.

http://dx.doi.org/10.1590/S0044-59672012000200002

Araújo, C. B. (2011). Composição florística e estrutura de uma floresta densa de terra firme explorada seletivamente no município de Moju, Pará (123 p). Belém: Dissertação de Mestrado, Universidade Federal Rural da Amazônia.

Brasil-Ministério da Minas e Energia. (1982). Levantamento dos re- cursos naturais-Vol. 20. Projeto RADAMBRASIL. Brasil: Departamento de Produção Mineral.

Calegário, N. (1998). Estudo da regeneração natural, visando à recuperação de áreas degradadas e o manejo florestal. In J. R. S. Scolforo, (Ed.), Manejo florestal (pp. 301-426). Minas Gerais: Universidade Federal de Lavras.

FAO-Food and Agricultural Organization of the United Nations (1971). Silvicultural research in the Amazon National Forestry School (192 p). Curitiba: FAO.

Fontana, C. S., Bencke, G. A., \& Reis, R. E. (2003). Livro vermelho da fauna ameaçada de extinção no Rio Grande do Sul (632 p). Porto Alegre: EDIPUCRS.

Frances, L. M. B., Carvalho, J. O. P., \& Jardim, F. C. (2007). Mudanças ocorridas na composição florística em decorrência da exploração florestal em uma área de floresta de terra firme na região de Paragominas, PA. Acta Amazônica, 37, 219-228. http://dx.doi.org/10.1590/S0044-59672007000200007

Gama, J. R. V., Botelho, S. S., \& Bentes-Gama, M. M. (2002). Composição florística e estrutura da regeneração natural de floresta secundária de várzea baixa no estuário amazônico. Universidade Fed- 
eral de Viçosa,Viçosa, Minas Gerais. Revista Árvore, 26, 559-566.

Gama, J. R. V., Botelho, S. S., Bentes-Gama, M. M., \& Scolforo, J. R. R. (2003). Estrutura e potencial futuro de utilização da regeneração natural de floresta de várzea alta no municipio de Afua, estado do Pará. Ciência Florestal, 13, 71-82.

Gomez, J. W. Le. (2011). Regeneración natural de nueve especies maderables en un bosque intervenido de la Amazonia Boliviana. Acta Amazonica, 41, 135-142.

http://dx.doi.org/10.1590/S0044-59672011000100016

Higushi, N., Jardim, F. C. S., Santos, J., \& Alencar, J. C. (1985). Bacia 3-Inventário diagnóstico da regeneração natural. Acta Amazônica, $15,199-233$.

Hirai, H. H., Carvalho, J. R. C., Silva, J. N. M., Carvalho, J. O. P., \& Queiroz, W. T. (2012). Efeito da exploração florestal de impacto reduzido sobre a regeneração natural em uma floresta densa de terra firme no município de Paragominas na Amazônia brasileira. Scientia Forestalis, Piracicaba, 40, 306-315.

Instituto Brasileiro do Meio Ambiente e dos Recursos RenováveisIBAMA (2008). Lista oficial de espécies da flora brasileira ameaçada de extinção. Brasília: Diário Oficial da República Federativa do Brasil.

Jardim, F. C. S., \& Hosokawa, R. T. (1986/1987). Estrutura da floresta equatorial úmida da estação experimental de silvicultura tropical do INPA. Manaus, AM. Acta Amazônica, 16-17, 411-508.

Jardim, F. C. S., Serrão, D. R., \& Nemer, T. C. (2007). Efeito de diferentes tamanhos de clareiras, sobre o crescimento e a mortalidade de espécies arbóreas, em Moju-PA. Acta Amazônica, 37, 37-48. http://dx.doi.org/10.1590/S0044-59672007000100004

Lima Filho, D. A., Revilla, J., Coêlho, L. S., Ramos, J. F., Santos, J. L.,
\& Oliveira, J. G. (2002). Regeneração natural de três hectares de floresta ombrófila densa de terra firme na região do Rio Urucu-AM, Brasil. Acta Amazônica, 32, 555-569.

Myers, N. (1992). The primary source: Tropical forests and our future (416 p). New York: W. W. Norteon Inc.

Narvaes, I. S., Longhi, S. J., \& Brena, D. A. (2008). Florística e classificação da regeneração natural em floresta ombrófila mista na floresta nacional de São Francisco de Paula, RS. Ciência Florestal, 18, 233-245.

OIMT-Organização Internacional de Madeiras Tropicais (1990). Diretrizes da OIMT para o manejo sustentado de florestas tropicais naturais (18 p). Malaysia: OIMT.

Park, A., Justiniano, M. J., \& Fredericksen, T. S. (2005). Natural regeneration and environmental relationships of tree species in logging gaps in a Bolivian tropical forest. Forest Ecology and Management, 217, 147-157. http://dx.doi.org/10.1016/j.foreco.2005.05.056

Péllico Netto, S., \& Brena, D. A. (1997). Inventário florestal (p. 316). Curitiba: The Authors Publhisher.

Schneider, R. R. (2000). Amazônia sustentável: Limitantes e oportunidades para o desenvolvimento rural (58 p). Belém: Imazon.

Scolforo. R. S. (1998). Manejo florestal-UFLA/FAEP/DCF (438 p). Lavras: Universidade Federal de Lavras.

Volpato, M. M. L. (1994). Regeneração natural em uma floresta secundaria no domínio de Mata Atlântica: Uma analise fitossociologica (123 p). Dissertação de Mestrado, Viçosa: Universidade Federal de Viçosa.

Zimmerman, B., \& Kormos, C. (2012). Prospects for sustainable logging in tropical forests. BioScience, 62, 479-487. http://dx.doi.org/10.1525/bio.2012.62.5.9 